\title{
EMPLOYEE ENGAGEMENT TERHADAP EMPLOYEE PERFORMANCE (SEBUAH STUDI LITERATUR)
}

\author{
Tedy Ardiansyah \\ Universitas Indraprasta PGRI \\ Email: tedyardiansyah@unindra.ac.id \\ Diterima: 6 Juni 2020; Direvisi: 24 Juli 2020; dipublikasikan: 28 Agustus 2020
}

\begin{abstract}
ABSTRAK
Kajian Literatur adalah membentuk suatu meta analisis atau konstruk teori dalam memcari kebenaran peneletian. Tujuan penelitian ini adalah untuk mengetahui perbandingan dari kajian literature jurnal dimana nanti akan membentuk suatu model literatur yang tepat. Metode umum diimplementasikan dalam penelitian ini adalah penelitian kualitatif dimana pendekatan yang dilakukan melalui studi literature, yaitu penelitian yang mengkaji secara kritis pengetahuan, gagasan atau temuan, serta memberikan kontribusi teoretis dan metodologis terhadap objek kajian. Hasil penelitian ini menunjukkan suatu reka cipta penempatan posisi variabel yang tepat untuk Employee Engagement membentuk model hasil riset yang tepat sebagai bahan referensi dan mengetahui dominasi jenis referensi jurnal, untuk kajian sumber daya manusia termasuk data sampel, jenis penelitian serta kegiatan bisnis atau usaha.
\end{abstract}

Kata kunci: employee engagement, employee performance

\begin{abstract}
A literature review is to form a meta-analysis or theoretical construct in finding the truth of the research. The purpose of this study is to determine the comparison of the journal literature review which will later form an appropriate literature model. The general method implemented in this research is qualitative research where the approach is carried out through literature studies, namely research that critically examines knowledge, ideas, or findings, and provides theoretical and methodological contributions to the object of study. The results of this study indicate an inventive placement of the appropriate variable positions for Employee Engagement to form an appropriate research result model as reference material and to determine the dominance of journal reference types, for human resource studies including sample data, types of research and business or business activities.
\end{abstract}

Keywords: employee engagement, employee performance 


\section{PENDAHULUAN}

Di era kontemporer, sumber daya manusia memiliki peran penting dalam organisasi saat ini yang ingin mendapatkan keunggulan kompetitif di pasar tenaga kerja internasional dan asli. Dengan demikian, tenaga kerja dianggap sebagai aset strategis dalam organisasi mana pun untuk perumusan dan implementasi strategi. Namun, retensi karyawan telah menjadi perhatian utama bagi banyak organisasi (Hausknecht, J.P., Rodda, J. and Howard, 2009). di lingkungan tempat kerja yang dinamis saat ini, individu menjadi semakin frustrasi dan teralienasi dengan pekerjaan (Bunting, 2011) dan sebaliknya mencari peluang untuk ekspresi diri dan pemenuhan yang lebih besar. Oleh karena itu, para peneliti menyoroti pentingnya keterlibatan karyawan (EE) yang memberikan motivasi intrinsik dan membantu menyelaraskan kepentingan karyawan dengan organisasi merek (Chalofsky, 2003).

Keterlibatan karyawan secara umum didefinisikan sebagai tingkat komitmen dan Keterlibatan karyawan terhadap organisasi dan nilai-nilainya. Ketika sebuah karyawan terlibat, dia menyadari tanggung jawabnya dalam tujuan bisnis dan memotivasi rekan-rekannya untuk kesuksesan tujuan organisasi. Aksi positif karyawan dengan tempat kerjanya dan sistem penilaian adalah dianggap sebagai korelasi emosional, baik pada seorang karyawan maupun pekerjaan dirinya sendiri. Memanfaatkan anggota organisasi untuk peran pekerjaan mereka, keterlibatan orang melakukan dan menjalankan diri mereka secara fisik, kognitif, dan secara emosional selama kegiatan mereka lakukan. Ada berbagai faktor yang menentukan dalam mengidentifikasi variabel-variabel kunci melalui survei literatur dan menggambarkan keterlibatan karyawan dan mengidentifikasi kekuatan dampak karyawan keterlibatan pada kinerja karyawan. Konsep telah berkembang dengan mempertimbangkan berbagai perilaku yang ditunjukkan oleh beberapa karyawan yang produktif secara positif.

Kinerja karyawan secara generalis adalah hasil yang dicapai dan dicapai dibuat di tempat kerja. Kinerja mengacu pada menjaga rencana adalah tujuan untuk pencapaian. Meskipun evaluasi kinerja adalah bagian pokok dari manajemen kinerja(Cardy, 2004), kinerja individu atau organisasi sangat bergantung pada semua kebijakan, implementasi, dan fitur desain organisasi organisasi. Perspektif integratif ini mewakili pendekatan konfigurasi untuk strategis Sumber Daya Manusia (SDM) yang berpendapat bahwa pola kegiatan SDM, sebagai lawan dari aktivitas tunggal, diperlukan untuk mencapai tujuan organisasi (Delery, J.E. and Doty, 1996). Keterlibatan karyawan adalah salah satu penentu utama mendorong tingkat kinerja karyawan yang tinggi, seperti yang terus-menerus ditunjukkan dalam sejumlah studi (Macey, W.H., et al, 2009). Makalah ini bertujuan untuk belajar penentu keterlibatan karyawan dan kekuatan dampaknya terhadap kinerja karyawan.

Tujuan utama penulisan artikel guna mengetahui hubungan antara employee engagement terhadap employee performance atau keterikatan karyawan melalui studi literatur yang relevan, yaitu dengan mengkaji dan membandingkan hasil penelitian dari sepuluh (10) jurnal ilmiah terindeks sangat bereputasi atau terdaftar dalam cakupan scopus tentang hubungan antara employee engagement atau keterikatan karyawan terhadap employee performance, muaranya adalah membentuk hipotesis dimana hal ini diperkuat dari scientist research. perbedaan pasti akan muncul dari penelitian yang satu dengan yang lainnya, baik dari objek yang dijadikan sebagai sampel riset, banyaknya jumlah sampel yang dipakai untuk riset, metode penelitian yang diaplikasikan, penempatan posisi dari variabel maupun hasil dari riset itu sendiri. Hasil penelitian saat ini menunjukkan gap atau disparitas yang sangat signifikan, di satu sisi kebijakan employee engagement mempunyai hubungan employee performance berpengaruh positif (Nazir \& Islam, 2017) akan tetapi, hasil penelitian lain menemukan bahwa employee engagement berpengaruh negatif terhadap employee performance(Arslan \& Roudaki, 2019, Joplin, Greenbaum, Wallace, \& Edwards, 2019) atau disisi lain engagement employee bisa menjadi variabel eksogen_(Cesário \& Chambel, 2017, J.,Anitha, 2014, Bedarkar \& Pandita, 2014) 
variabel intervening (Nazir \& Islam, 2017, Ayu Putu Widani Sugianingrat et al., 2019, Arslan \& Roudaki, 2019), gap atau disparitas ini menarik untuk diketahui letak perbedaannya dan berusaha untuk menjawab sebuah hipotesis.

\section{Employee Engagement}

Keterlibatan karyawan adalah masalah kepedulian terhadap para pemimpin dan manajer dalam organisasi di seluruh dunia, sebagaimana adanya diakui sebagai elemen penting dalam menentukan efektivitas organisasi, inovasi, dan daya saing. Istilah keterlibatan karyawan berpusat pada penelitian di universitas, semua beranggapan bahwa sebagian besar adalah masalah konsultasi praktis sampai era 1990-an. Meskipun sejak itu, konsep ini menarik perhatian yang lebih besar dari para sarjana dalam disiplin ilmu seperti bisnis dan manajemen, psikologi dan perilaku organisasi, itu sama dengan ada kekurangan literatur akademik(Kular et al, 2008), Ini adalah latihan yang sulit dan ekstensif untuk mendefinisikan keterlibatan dan menguraikan ruang lingkupnya. Setiap studi tentang keterlibatan karyawan mengeksplorasi dalam konteks yang berbeda. Akibatnya, tidak ada definisi universal dan bulat tentang pengukuran keterlibatan karyawan. Selain itu, keterlibatan karyawan telah dikaitkan dengan peneliti lain yang baik dan konstruksi yang mapan seperti 'komitmen organisasi', 'Organizational Citizenship Behavior', 'Keterlibatan Kerja',' Arus', dll. Dengan demikian, untuk memahami konstruk keterlibatan karyawan dengan kejelasan yang lebih besar, kita harus bergantung pada beberapa riset tentang masalah tersebut.

Makalah ini menyajikan beberapa definisi keterlibatan karyawan dalam urutan kronologis. Dengan demikian, ini membantu memahami evolusi konsep. Sepotong literatur keterlibatan sebelumnya oleh Goffman (1961) mengemukakan bahwa konsep keterlibatan berakar pada teori peran. Dia mendefinisikan keterlibatan sebagai keterlibatan spontan dalam peran dan investasi nyata dari perhatian (seperti dikutip dalam Wildermuth, C. \&Pauken, (2008)).Katz, D. And Kahn,(1966) menekankan pada kebutuhan general untuk pekerja untuk terlibat dengan pekerjaan dan organisasi mereka.

Meskipun pekerjaan mereka tidak menggunakan istilah 'keterlibatan karyawan' secara langsung, ia mengakui perlunya keterlibatan dan hubungannya dengan efektivitas organisasi. Csikszentmihalyi(1982) menyatakan keterlibatan karyawan sebagai konsep aliran, di mana aliran adalah sensasi holistik yang dialami karyawan ketika mereka benar-benar terlibat dalam pekerjaan mereka. W. Kahn, yang dianggap sebagai senior akademik dari gerakan keterlibatan karyawan, mengembangkan konsep 'keterlibatan pribadi'. Dalam karyanya, ia mendefinisikan keterlibatan kerja pribadi sebagai memanfaatkan anggota organisasi untuk peran pekerjaan mereka; dalam keterlibatan, orang-orang menggunakan dan mengekspresikan diri mereka secara fisik, pola berpikir dan pola emosional, dalam pertunjukan peran.

Untuk menjelaskan fenomena tersebut, Kahn mengaitkan tiga kondisi, yaitu. keamanan psikologis, psikologis kebermaknaan, dan ketersediaan psikologis, yang mengarah pada keterlibatan karyawan. Karyawan mengalami keamanan psikologis di hadapan anggota lain ketika mereka menghubungkan diri mereka dengan pertunjukan peran mereka dan mereka diberi sumber daya pribadi yang cukup untuk mendedikasikan diri untuk pertunjukan tersebut. Pekerjaan mereka cukup berarti. Karena karyawan merasa aman secara psikologis dan pekerjaan mereka bermakna bagi mereka, mereka tersedia secara psikologis. Dengan demikian, kondisi ketersediaan psikologis mengacu pada situasi, di mana karyawan dan memanfaatkan seluruh diri mereka secara terpadu dan terfokus untuk meningkatkan kinerja peran mereka. Dengan demikian, definisi Kahn tentang keterlibatan karyawan menunjukkan bahwa keterlibatan karyawan adalah konstruksi multi-segi. Kahn mengklaim bahwa semakin banyak dari diri kita yang kita berikan pada suatu peran, semakin menyenangkan dan nyaman kinerja kita.

Goffman dan Kahn keduanya mengamati bahwa individu tidak menetapkan diri mereka sama rata untuk setiap peran. Shaufeli.et al,(2002) mendefinisikan keterlibatan sebagai "keadaan pikiran yang benar, bahagia, menyangkut pekerjaan berhubungan dengan semangat, pengabdian 


\section{sosio e-kons}

Volume 12, No. 2, Agustus 2020, pp. 156-171

e-ISSN: $2502-5449$

p-ISSN: 2085-2266

DOI : 10.30998/sosioekons.v12i02.6444

dan implementasi." May, et al (2004) menguji model Kahn dan temuan mereka mendukung bahwa kondisi psikologis kebermaknaan, keamanan dan ketersediaan korelasi positif dengan pelaksanaan.

Robinson (2004) mendefinisikan keterlibatan sebagai satu langkah di depan komitmen. Mereka mendefinisikan keterlibatan karyawan sebagai sikap positif karyawan mempengaruhi organisasi dan nilai tersebut. Karyawan memiliki kesadaran akan konteks bisnis dan bekerja untuk meningkatkan efektivitas kerja dan organisasi. Lebih penting lagi, penelitian ini menekankan sifat dua arah dari keterlibatan karyawan.

Definisi penting lain tentang keterlibatan muncul dari kontribusi shaufeli.W.B. and Bakker (2004). Mereka menciptakan istilah 'pelibatan kerja' dan lebih lanjut, mendefinisikannya sebagai "kondisi positif cognitif, memuaskan, terkait pekerjaan yang berbentuk semangat, pengabdian dan penyerapan". Dengan demikian, keterlibatan ditandai dengan kekuatan, dedikasi, dan penyerapan. Hewitt Associates (2004), mengembangkan skala 18-item untuk mengukur keterlibatan karyawan. Ini mendefinisikan keterlibatan sebagai keadaan tempat individu secara emosional dan intelektual berkomitmen untuk organisasi atau kelompok, yang diukur dengan tiga perilaku utama: Katakan (Karyawan berbicara secara positif tentang organisasi kepada orang lain di dalam dan luar), Tetap (Karyawan menampilkan dorongan yang positif untuk menjadi anggota organisasi) dan Berusaha (Karyawan mengerahkan upaya keras dan ikut memutuskan dalam perilaku yang menghasilkan terhadap kesuksesan bisnis). Pegawai yang terlibat menunjukkan tiga perilaku ini, yaitu katakan, tetap, dan berusaha.

Saks, (2006) memperluas konsep keterlibatan karyawan untuk mencakup dua aspek penting, keterlibatan kerja dan keterlibatan organisasi. Dipercaya secara luas bahwa pekerjaannya memulihkan keterlibatan karyawan sebagai konstruksi serius. Flemming, J.H. and Asplund (2007) dari Gallup, dalam buku yang berjudul Human Sigma: Mengelola Karyawan, pertemuan dengan pelanggan mendefinisikan keterlibatan karyawan sebagai "kemampuan untuk menangkap seluruh hati, dan jiwa karyawan Anda untuk menanamkan hasrat dan hasrat intrinsik untuk keunggulan." Mereka lebih lanjut menunjukkan bahwa karyawan yang terlibat ingin organisasi mereka sukses karena mereka merasa terhubung secara emosional, sosial, dan bahkan secara spiritual dengan misi, visi, dan tujuannya.

CIPD (2006) menerbitkan laporan, berjudul, 'Bagaimana Terlibatnya Karyawan Inggris', yang menyajikan temuan-temuan dari survei tentang sikap dan keterlibatan karyawan, yang mencakup sampel 2000 karyawan di seluruh Inggris. Penelitian ini dilaksankan oleh CIPD Kingston Business School plus Ipsos MORI. Laporan ini mendefinisikan keterlibatan karyawan sebagai "hasrat untuk bekerja ', yang melibatkan perasaan positif tentang pekerjaan Anda, serta dipersiapkan untuk bekerja lebih keras untuk memastikan Anda melakukan pekerjaan Anda sebaik mungkin sesuai dengan kemampuan Anda". Studi ini mengidentifikasi tiga dimensi keterlibatan karyawan: 1) keterlibatan emosional - sangat terlibat secara emosional dengan pekerjaan seseorang; 2) keterlibatan kognitif - fokus sangat keras saat bekerja; dan 3) keterlibatan fisik - bersedia 'bekerja keras' untuk majikan Anda.

Studi ini dan laporan lengkap selanjutnya oleh Truss (2006) menetapkan bahwa pandangan Kahn tentang karyawan keterlibatan dioperasionalkan dalam survei besar yang mencakup sampel pada 2000. Dalam laporan sementara oleh Kingston Business School ke CIPD, Gatenby et al (2008) mengamati, "keterlibatan adalah tentang menciptakan peluang bagi karyawan untuk terhubung dengan rekan kerja, manajer, dan organisasi yang lebih luas . Ini juga tentang menciptakan lingkungan tempat karyawan termotivasi untuk ingin tersalurkan dengan pekerjaan masing-masing dan benar-benar peduli untuk melakukan pekerjaan dengan baik".

Macey, W.H. dan Schneider, 2008), dalam karya mereka, berkomentar bahwa definisi keterlibatan dapat diklasifikasikan menjadi tiga pangkalan yang berbeda. Ketika pertunangan digambarkan sebagai 'apa adanya', itu sedang diklasifikasikan berdasarkan 'kondisi psikologis'. 


\section{sosio e-kons}

Volume 12, No. 2, Agustus 2020, pp. 156-171

e-ISSN: 2502-5449

p-ISSN: 2085-2266

DOI : 10.30998/sosioekons.v12i02.6444

Ini diklasifikasikan sebagai 'keterlibatan perilaku' ketika satu analisis dari perilaku yang disebabkannya. Keterlibatan juga ditentukan atas dasar sikap terhadap pekerjaan (sifat) seseorang. Mereka lebih lanjut menyarankan bahwa 'keterlibatan sifat' akan tercermin dalam 'keadaan psikologis' individu, yang menghasilkan 'keterlibatan perilaku'. Mereka mendefinisikan keterlibatan sebagai "upaya diskresi atau bentuk upaya atau perilaku dalam peran atau peran ekstra di luar mempertahankan status quo dan sebaliknya fokus pada memulai atau mendorong perubahan dalam arti melakukan sesuatu yang lebih dan / atau berbeda".

Newman, D.A. and Harrison, (2008) mendefinisikan keterlibatan sebagai kehadiran simultan dari tiga perilaku di Indonesia karyawan, yaitu, kinerja mereka dalam pekerjaan, perilaku kewarganegaraan, dan keterlibatan.

Cook, (2012) mendefinisikan keterlibatan sebagai "seberapa positif karyawan berpikir tentang organisasi, merasakan tentang organisasi dan proaktif dalam kaitannya dengan pencapaian tujuan organisasi bagi pelanggan, kolega, dan pemangku kepentingan lainnya".

\section{Employee Performance}

kinerja adalah result yang didapatkan dari anggota organisasi baik organisasi tersebut bersifat keuntungan semata dan non keuntungan semata yang didapatkan selama kurun waktu tertentu (Fahmi, 2014). Kinerja merupakan hasil kerja korelasi terhadap tujuan organisasi, memberikan input aktivitas ekonomi. kinerja adalah hal bagaimana melakukan pekerjaan dan bagaimana cara mengerjakannya (Wibowo, 2007). Kinerja adalah sesuatu yang telah didapatkan oleh pegawai dari aktivas yang dijalani dalam bekerja (Sutrisno, 2016). kinerja adalah tingkat mendapatkan result atas pelasksanaan tugas tertentu (Rivai, 2009). Kinerja adalah paparan tentang hasil implementasi yang didapatkan dari suatu kegiatan/program/kebijaksanaan dalam mencapai tujuan yang dicapai, misi dan visi perusahan tertulis dalam perumusan skema strategik suatu organisasi (Fahmi, 2014). Memaparkan mengenai bagaimana mengatur kinerja dan bagaimana menempatkannya dalam implementasinya. Terdapat empat faktor pokok dalam kinerja, yaitu awal, proses, hail, dan produk (winanti, 2011). Input: skill, knowledge, dan profesional dalam melaksanakan pekerjaan rutinitas. Hal ini terkaik indikator individual. Process : Bagaimana individu memiliki kepercayaan dalam melaksanakan pekerjaan mereka. Hal ini menyangkut kompetensi yang dibawa dalam pekerjaan dalam mendukung tanggung jawab. Output : Hasil terukur yang dicapai oleh individu selaras dengan bagian kinerja yang dicapai dalam melaksanakan tugas-tugas mereka. Hal ini merupakan parameter kinerja yang didapatkan seseorang. Hasil: Efek apa yang telah didapat oleh kinerja individu dari hasil kelompok, departemen, unit dan organisasi. Ada lima kinerja karyawan secara individu, yaitu Kualitas, artinya result kegiatan yang telah dijalankan mendekati sempurna, dengan menyesuaikan beberapa cara tepat dari pelaksanaan kegiatan guna memenuhi tujuan yang direncanakan dari hasil kegiatan. Kuantitas, yaitu hasil yang diinginkan dan di implementasikan dalam istilah unit satuan putaran kegiatan yang diselesaikan. Pengetahuan dan keterampilan, yaitu pengetahuan dan keterampilan yang dimiliki oleh karyawan. Tepat waktu, yaitu kegiatan yang telah dijalankan pada kegiatanawal yang direncankan, dilihat dari sudut bagian dari hasil yang diinginkan serta memanfaatkan waktu yang tersedia untuk aktivitas lain. Komunikasi, yaitu hubungan atau interaksi dengan sesama rekan kerja dalam organisasi.

\section{METODE}

Metode atau metodologi adalah proses, prinsip, prosedur yang dijalankan untuk mengetahui masalah dan mencari jawaban yang dihipotesiskan. Dengan penjelasan lain, metodologi adalah suatu approach bersifat generalsi untuk mengulas topik penelitian (Deddy mulyana, 2004). Jenis pendekatan yang digunakan adalah pendekatan kualitatif, yaitu penelitian 
yang digunakan untuk riset mengenai objek alamiah, peneliti adalah sebagai bagian dari validitas riset, teknik mendapatkan dilakukan secara kualitatif, analisis data adalah induktif, dan hasil riset kualitatif lebih memfokuskan makna dibandingkan generalisasi (Sugiyono, 2014). Jenis penelitian termasuk dalam penelitian eksploratif yaitu dilakukan untuk mengetahui dan menjelaskan permasalahan yang awalnya peneliti hanya memahami permasalahan yang ada secara umum, baru kemudian peneliti melakukan penelitian. Penelitian adalah bagian dari kesinambungan kegiatan ilmiah baik untuk keperluan collection data, menarik kesimpulan atas gejala-gejala khusus dalam bentuk empirik(Bungin B., 2011). Metode penelitian menggunakan kajian literatur yaitu peneliti mengkaji secara saksama akan literature yang dibutuhkan dalam riset (Nazir, 2014) dan juga mengkombinasikan dengan menggunakan wawancara pada informan yang diperlukan dalam riset. Metode penelitian yang digunakan adalah studi literatur secara sistematis(Espitia et al, 2016). Adapun teknik collection data dijalankan dengan menggunakan data sekunder dengan membandingkan dari wawancara dan data pendukung lainnya, informan adalah pucuk pimpinan dari platform e-commerce digital business.

Dalam penelitian kualitatif pendekatan studi literatur ini, peneliti menggunakan tools NVivo 10, dimana tools ini telah diakui secara internasional untuk melakukan penelitian kualitatif. Dalam NVivo, sumber data riset (internal), sumber data riset eksternal (luar), tulisantulisan peneliti dalam data collections (memos), dan kerangka atau bingkai (framework matrices). Sumber internal dalam text ini merupakan bagian sumber data penelitian kualitatif yang dapat tampil di dalam NVivo, misalnya, rekaman atau record wawancara, transkrip wawancara, catatan-catatan dalam melakukan riset, picture, table data dalam riset survey, isi situs tertentu, pengaturan dan termasuk video-video(Bandur, 2016).

\section{HASIL DAN PEMBAHASAN}

Hasil yang didapatkan dari kajian literatur employee engagement terhadap employee performance dijelaskan dalam bentuk tabel di bawah, dimana 10 jurnal membentuk konstruk teori atau meta analysis diambil dari rentang tahun 2013 sampai dengan 2019. Karena keterbatasan pembahasan variabel employee engagement dengan employee performance, hanya 10 jurnal terindeks bereputasi (scopus) tersebut yang menjadi pilihan dari puluhan jurnal lainnya.

Tabel 1. Perbandingan Jurnal

\begin{tabular}{|c|c|c|c|}
\hline No & $\begin{array}{c}\text { Jurnal } \\
\text { \& Author }\end{array}$ & Judul & Hasil \\
\hline 1 & $\begin{array}{l}\text { South Asian Journal of } \\
\text { Business Studies, } 2017 \\
\text { Vol. 6(1) 98-114 }\end{array}$ & $\begin{array}{l}\text { Meningkatkan } \\
\text { komitmen organisasi } \\
\text { dan kinerja karyawan } \\
\text { melalui keterlibatan } \\
\text { karyawan }\end{array}$ & $\begin{array}{l}\text { Hasil mengungkapkan pengaruh } \\
\text { positif dari dukungan organisasi } \\
\text { yang dirasakan pada kinerja } \\
\text { karyawan dan komitmen afektif. } \\
\text { Selain itu, hubungan ini juga } \\
\text { ditemukan dimediasi oleh } \\
\text { keterlibatan karyawan. }\end{array}$ \\
\hline 2 & $\begin{array}{l}\text { International Journal } \\
\text { of Sociology and } \\
\text { Social Policy } 2019 \\
\text { Vol. 39,1-2, } \\
\text { 118-137 } \\
\text { Muhammad Arslan }\end{array}$ & $\begin{array}{l}\text { Meneliti peran } \\
\text { keterlibatan karyawan } \\
\text { dalam hubungan } \\
\text { antara sinisme } \\
\text { organisasi dan kinerja } \\
\text { karyawan }\end{array}$ & $\begin{array}{l}\text { Temuan analisis korelasi dan } \\
\text { regresi mengungkapkan bahwa } \\
\text { OC memiliki hubungan negatif } \\
\text { yang signifikan dengan EP. Oleh } \\
\text { karena itu, perawatan pasien } \\
\text { dikompromikan dalam organisasi } \\
\text { sampel karena kinerja karyawan }\end{array}$ \\
\hline
\end{tabular}


Jamal Roudaki

3 International Journal of Productivity and Performance

Management, 2019

Vol. 68 Issue 2

P 319-339

Ida Ayu Putu et al

4 Procedia - Social and Behavioral Sciences, 2014

Vol. 133

P $106-115$

Madhura Bedarkar, Deepika Pandita
Keterlibatan karyawan dan OCB sebagai penengah pada kinerja karyawan

Sebuah studi tentang pendorong keterlibatan karyawan yang memengaruhi kinerja karyawan
$5 \quad$ Knowledge and Process Management 2017

Vol 24 Issue 2

P 152-158

Francisco Cesário

Maria José Chambel yang lebih buruk. Selain itu, temuan juga mengungkapkan bahwa EE memiliki efek moderat pada hubungan antara OC dan EP. Oleh karena itu, manajemen rumah sakit perlu meningkatkan EE untuk mengurangi sinisme dan meningkatkan kinerja.

Keterlibatan karyawan mampu memediasi kepemimpinan etis dalam meningkatkan kinerja karyawan. Ketiga, OCB akan dapat memainkan peran dalam memediasi pengaruh kepemimpinan etis terhadap kinerja karyawan jika ia melewati peran mediasi dalam keterlibatan karyawan terlebih dahulu.

Keterlibatan Karyawan adalah konsep yang semakin penting dalam 10 tahun terakhir. Organisasi saat ini menggunakan karyawan yang terlibat sebagai alat untuk mitra strategis dalam bisnis. Konsep keterlibatan karyawan kini semakin penting, karena banyak pengemudi telah diidentifikasi, yang memengaruhi kinerja dan kesejahteraan karyawan di tempat kerja. Ketika perusahaan di seluruh industri berusaha untuk bertahan dan naik di atas persaingan yang ketat, kesejahteraan fisik dan mental karyawan akan menjadi salah satu aspek penting yang perlu difokuskan oleh manajer SDM. Karenanya, keterlibatan karyawan saat ini dipandang sebagai sumber keunggulan kompetitif yang kuat di masa-masa sulit.

Mengkonfirmasi adanya hubungan positif antara kinerja dan komitmen afektif, komitmen normatif, dan keterlibatan kerja dengan keterlibatan yang menunjukkan hubungan yang lebih kuat. Kedua, hanya keterlibatan kerja yang relevan untuk menjelaskan kinerja 
6 Benchmarking ,2019

Swati Dhir, Archana Shukla

7 International Journal of Innovation

Management, 2017

Vol 21 No.7

P 1-30

Vishal Gupta et al
Peran citra organisasi dalam keterlibatan dan kinerja karyawan
Hubungan antara kepemimpinan, keterlibatan bekerja dan kinerja inovatif karyawan bukti empiris dari konteks R \& D India
8 Jurnal Internasional Faktor penentu Manajemen Produktivitas

Kinerja, 2014

Vol 63, Issue 3

P 308-323

Anitha J.

9 Journal of Business Ethics, 2019

Toby Joplin et al karyawan karena komitmen tidak menghadirkan kekuatan prediktor yang signifikan. Implikasi penting dari studi ini adalah bahwa pengusaha harus mengasumsikan relevansi pengembangan kondisi kerja yang memadai dan menantang, praktik sumber daya manusia, dan suasana sehingga karyawan dapat meningkatkan semangat mereka untuk pekerjaan yang mereka lakukan.

Temuan utama dari studi ini membantu karyawan dan juga pengusaha untuk memiliki pemahaman yang menyeluruh dan komprehensif untuk meningkatkan EE dan kinerja mereka dengan menciptakan citra organisasi yang positif dan konsisten.

Studi ini menemukan bahwa keterlibatan kerja berhubungan positif dengan perilaku kerja yang inovatif serta kinerja yang inovatif. Perilaku pemimpin memiliki efek tidak langsung yang signifikan pada perilaku kerja yang inovatif serta kinerja yang inovatif melalui keterlibatan kerja. Sementara efek total kepemimpinan pada perilaku kerja yang inovatif, efek total tidak signifikan untuk kinerja inovatif. Implikasi untuk teori dan praktik dibahas.

Ditemukan bahwa semua faktor yang diidentifikasi adalah prediktor keterlibatan karyawan ( $\mathrm{r}$ 2, 0,672), namun variabel yang memiliki dampak besar adalah lingkungan kerja dan hubungan tim dan rekan kerja. Keterlibatan karyawan memiliki dampak signifikan terhadap kinerja karyawan (r 2, 0,597).

Menggambar pada argumen teoretis dari disiplin psikologi, kami menyelidiki implikasi hak karyawan dalam pengaturan 
10 International Journal of Hospitality

Management, 2013

Vol 32 Issue 1

P 132-140

Osman M. Karatepe organisasi. Secara khusus, kami menggunakan teori keterlibatan tempat kerja untuk menyarankan bahwa adanya ketimpangan diantara mereka, karyawan yang memiliki hak tinggi cenderung untuk mengalami keterlibatan di tempat kerja. Selain itu, hubungan negatif antara hak karyawan dan keterlibatan di tempat kerja diperkuat ketika kepemimpinan etis rendah, namun dikurangi ketika kepemimpinan etis tinggi. Akhirnya, kami memperkirakan bahwa dalam kondisi kepemimpinan etis yang rendah, pengurangan dalam hubungan menjelaskan mengapa hak karyawan mengakibatkan kinerja yang terhambat. Efek yang dimediasi ini tidak berlaku ketika kepemimpinan etis tinggi. Kami menguji model teoritis kami menggunakan data lapangan dari karyawan dan pengawas langsung mereka di industri jasa keuangan $(\mathrm{N}=243)$. Hasil kami mendukung model teoritis kami. Implikasi teoritis dan praktis dibahas.

Kata kunci

Riset ini mengusulkan dan menguji model penelitian yang menyelidiki apakah fungsi keterlibatan kerja sebagai mediator dari efek praktik kerja berkinerja tinggi (HPWP) pada kinerja pekerjaan dan layanan pelanggan ekstra-peran. Hubungan-hubungan ini dinilai melalui LISREL 8.30 menggunakan pemodelan persamaan struktural (SEM). Data diperoleh dari karyawan hotel garis depan penuh waktu dan manajer mereka di wilayah Poiana Brasov di Rumania. Hasil menunjukkan bahwa keterlibatan kerja bertindak sebagai mediator penuh dari efek HPWP pada kinerja pekerjaan dan layanan 


\section{sosio e-kons}

Volume 12, No. 2, Agustus 2020, pp. 156-171

e-ISSN: 2502-5449

p-ISSN: 2085-2266

DOI : 10.30998/sosioekons.v12i02.6444

pelanggan ekstra-peran. Secara

khusus, HPWP, sebagaimana

diwujudkan oleh penilaian

karyawan garis depan tentang

pelatihan, pemberdayaan, dan

penghargaan, meningkatkan

keterlibatan kerja. HPWP

semacam itu pada gilirannya

memicu kinerja pekerjaan dan

layanan pelanggan ekstra-peran.

Implikasi dari hasil dibahas dan

jalan untuk penelitian masa depan

ditawarkan.

Sumber: dari berbagai jurnal terindeks bereputasi (scopus)

Dari matrik diatas menghasilkan beberapa pembahasan antara lain:

\section{Word Frequency Queries}

Yaitu mengeksplorasi kata yang paling sering ditemukan dalam data penelitian. Dengan tools analisis ini, kata-kata yang memilik arti yang sama dapat di klasifikasikann dalam group yang sama.

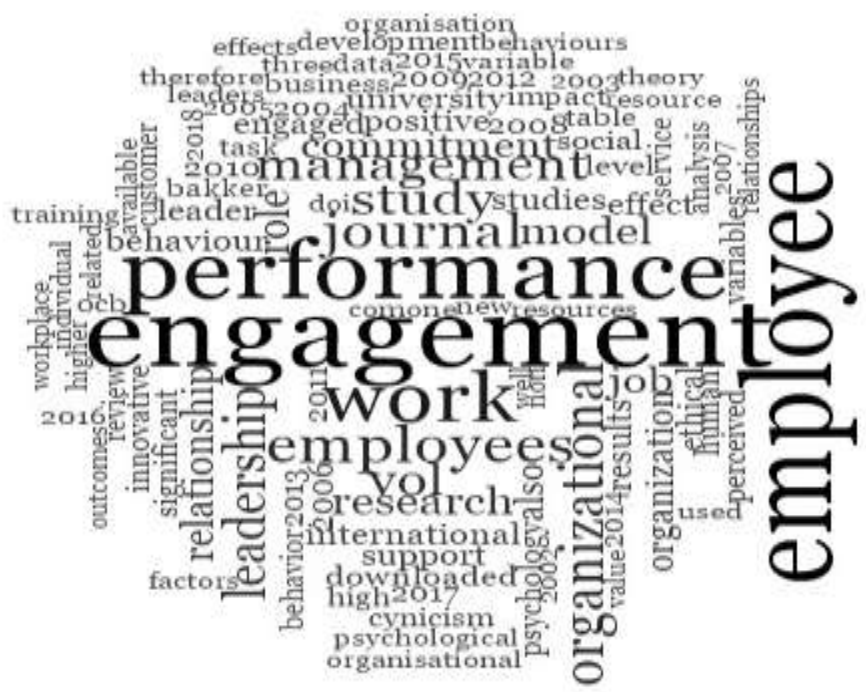

Gambar 1.Word Frequency Queries

Dari analisis diatas untuk kata yang paling dominan adalah Employee Performance dan Employee Engagement diartikan bahwa seluruh jurnal bereputasi berjumlah 10 seluruh fokus pada pembahasan mengenai Performance Employee (Kinerja Karyawan) dan Engagement Employee (keterlibatan karyawan) dimana ditandai dengan huruf tertulis tebal

\section{Analisis Klaster}

Membandingkan kata-kata yang terdapat dalam sumber data atau ingin membandingkan kesamaan kata-kata dalam tema-tema hasil koding yang tersimpan dalam nodes. Dalam Analisis Klaster ini dapat diukur mengenai korelasi (Pearson Coffecient). 


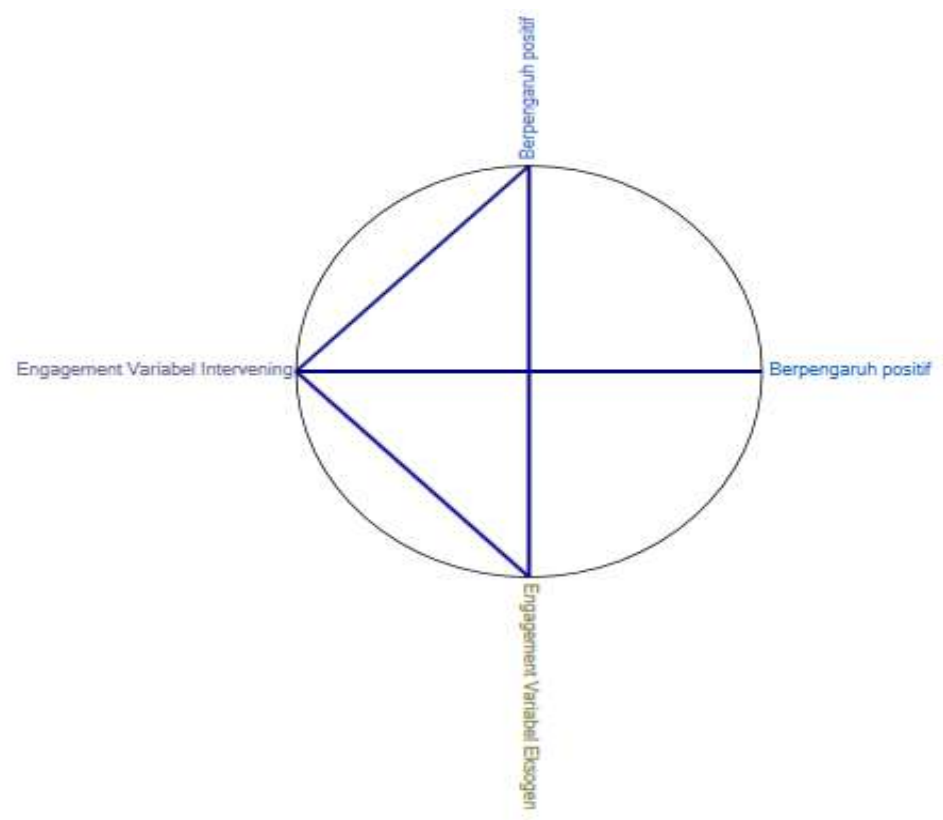

Gambar 2. Analisis Klaster

Dalam Gambar diatas bahwa garis biru menunjukan hubungan atau korelasi yang kuat antara Engagement Variabel Moderator dengan Tema Berpengaruh Positif sama halnya dengan Engagement Variabel Eksogen dengan Tema Berpengaruh Positif, singkat menunjukan hubungan yang kuat hubungan antara tema dengan tema.

Tabel 2. Analisis Klaster

\begin{tabular}{|c|c|c|}
\hline Code A & Code B & $\begin{array}{c}\text { Pearson correlation } \\
\text { coefficient }\end{array}$ \\
\hline $\begin{array}{l}\text { Nodes \Engagement Variabel } \\
\text { Intervening }\end{array}$ & $\begin{array}{l}\text { Nodes } \backslash \text { Engagement Variabel } \\
\text { Intervening } \backslash \text { Berpengaruh positif }\end{array}$ & 0.933095 \\
\hline $\begin{array}{l}\text { Nodes } \backslash \text { Engagement Variabel } \\
\text { Eksogen }\end{array}$ & $\begin{array}{l}\text { Nodes } \backslash \text { Engagement Variabel } \\
\text { Eksogen\Berpengaruh positif }\end{array}$ & 0.83832 \\
\hline $\begin{array}{l}\text { Nodes } \backslash \text { Engagement Variabel } \\
\text { Intervening }\end{array}$ & $\begin{array}{l}\text { Nodes \Vngagement Variabel } \\
\text { Eksogen }\end{array}$ & 0.807074 \\
\hline $\begin{array}{l}\text { Nodes } \backslash \text { Engagement Variabel } \\
\text { Intervening }\end{array}$ & $\begin{array}{l}\text { Nodes \Engagement Variabel } \\
\text { Eksogen } \backslash \text { Berpengaruh positif }\end{array}$ & 0.722812 \\
\hline $\begin{array}{l}\text { Nodes } \backslash \text { Engagement Variabel } \\
\text { Eksogen }\end{array}$ & $\begin{array}{l}\text { Nodes } \backslash \text { Engagement Variabel } \\
\text { Intervening\Berpengaruh positif }\end{array}$ & 0.642095 \\
\hline $\begin{array}{l}\text { Nodes } \backslash \text { Engagement Variabel } \\
\text { Intervening } \backslash \text { Berpengaruh positif }\end{array}$ & $\begin{array}{l}\text { Nodes } \backslash \text { Engagement Variabel } \\
\text { Eksogen\Berpengaruh positif }\end{array}$ & 0.595027 \\
\hline
\end{tabular}

Hasil analisis diatas baik dari Tabel 1 terlihat tema yang memiliki korelasi kuat (Pearson Coefficient) yaitu mendekati nilai 1 yaitu: Employee Engagement Variabel dan Employee Performance Exogen dengan tema Berpengaruh Positif, diartikan bahwa hal diatas sangat kuat hubungan nya, seperti pada 10 jurnal yang ada diintisarikan bahwa Employee Engagement Variabel selau mempunyai hubungan yang positif terhadap Employee Performance. 


\section{Project Map}

Salah satu fitur yang terdapat di NVivo untuk menampilkan hasil dari penelitian adalah berbentuk Map. Istilah yang digunakan sebelumnya pada NVivo adalah Model, namun kini sudah diganti dengan istilah Map. Project Map: Map yang bersumber dari coding yang telah dibuat sebelumnya, baik itu Files, Nodes, maupun Relationships, hal ini mengacu pada tematema hasil koding sehingga dapat mevisualisasikan hasil koding.

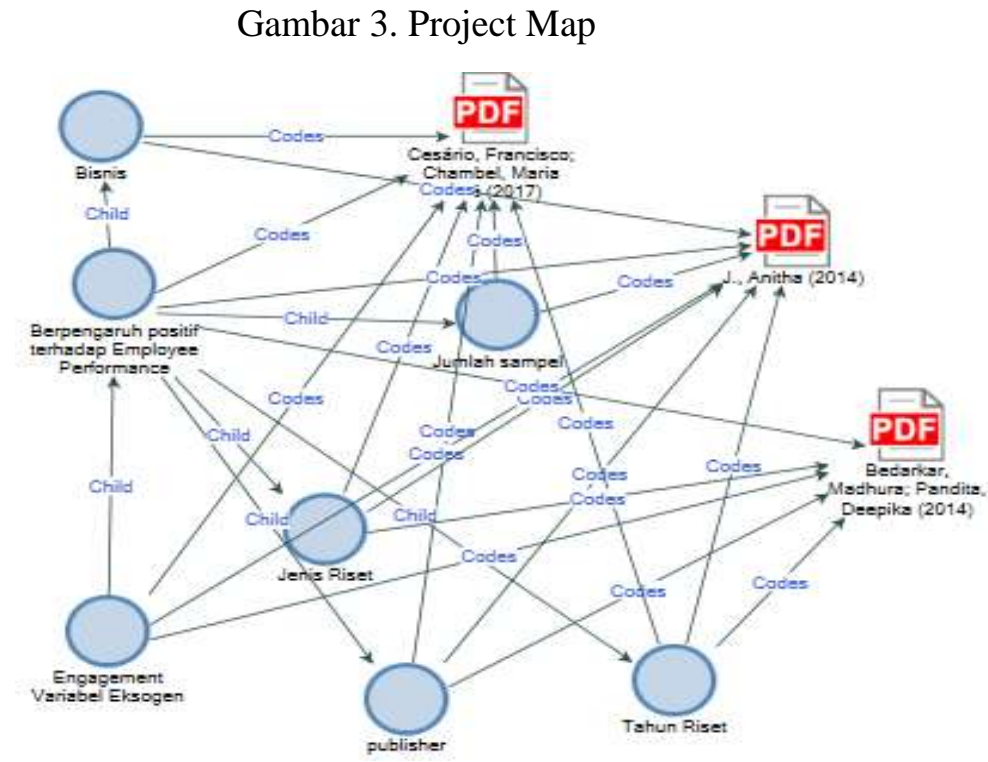

Gambar 4.Project Map1

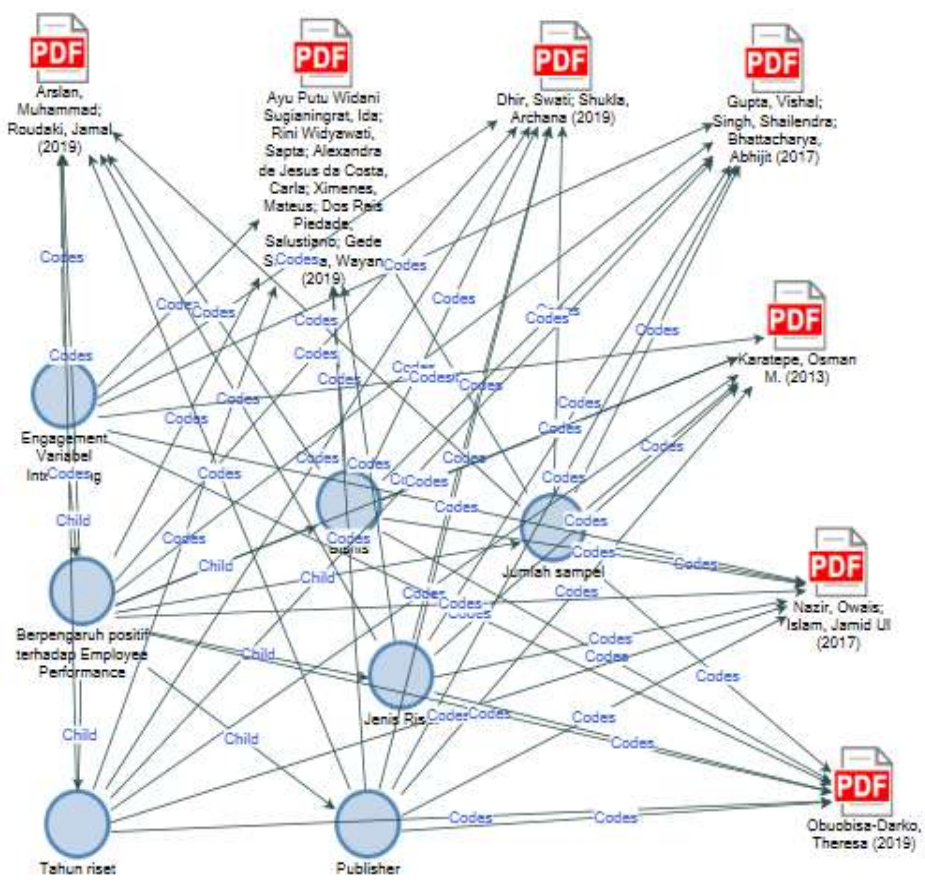

Dari Map atau model diatas bahwa masing masing 10 jurnal terpecah menjadi dua yaitu Employee Engagement menjadi Variabel Eksogen dan Variabel Mediator. Diartikan dari 10 jurnal bahwa Employee Engagement dapat menjadi Variabel Eksogen. Lebih detail kebawahnya 
masing-masing mempunyai kesamaan tema yaitu: Tahun Riset, Jenis Riset, Jumlah Sampel, Jenis Bisnis, dan Publisher Jumlah Sampel.

\section{Diagram perbandingan}

Diagram perbandingan pada dasarnya untuk membantu dalam membandingkan tematema secara khusus untuk menjelaskan perbandingan secara mendetail. Diagram ini juga membandingkan partisipan satu dengan ke lainnya atau data setting penelitian.

Gambar 5. Diagram perbandingan

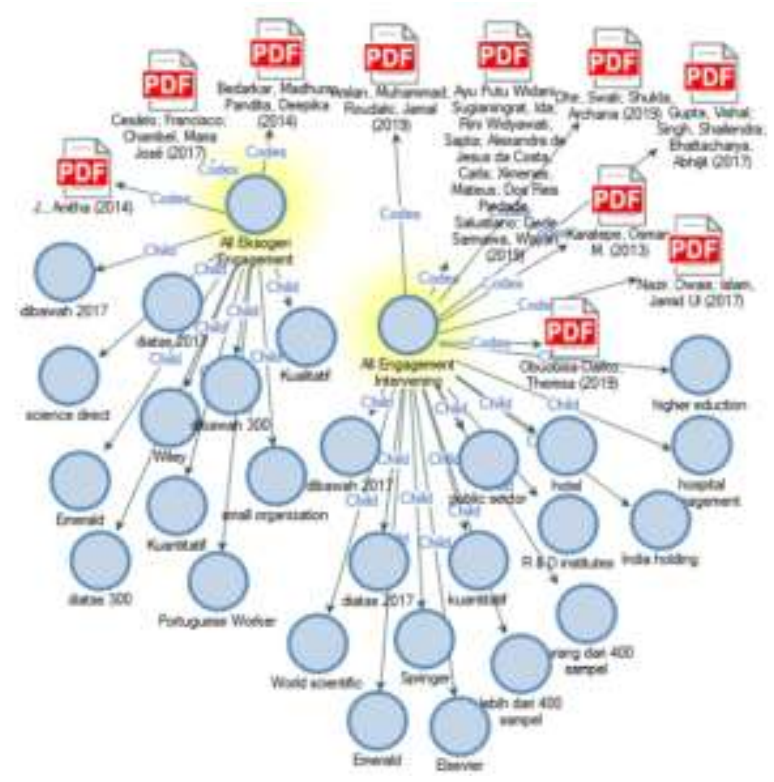

Dari gambar diatas bahwa dari 10 jurnal bereputasi terpecah menjadi 2 bagian yaitu: Employee Engagement Eksogen dan Employee Engagement Moderator.

1. Employee Engagement Eksogen terdiri dari 3 Jurnal dari J. Anitha(2014), Cesarino dan kawan-kawan(2017) serta Bedarkar dan kawan-kawan(2014), Jurnal terbagi menjadi dua yaitu dibawah 2017 sebanyak 2 jurnal dan diatas 2017 sebanyak 1 jurnal. Untuk Publisher hanya ada 3 yaitu Science Direct, Wiley dan Emerald. Sampel dibawah 300 sebanyak 1 jurnal dan sampel diatas 300 sebanyak 1 jurnal. Sedangkan jenis penelitian terbagi menjadi 2 kualitatif hanya 1 dan kuantitatif sebanyak 2. Kualitatif pendekatan dalam bentuk Literatur Review. Bisnis kegiatan Portuguese Worker dan Perusahaan Kecil masing masing sebanyak 1 jenis kegiatan usaha.

2. Employe Engagement Moderator terdiri dari 7 Jurnal yaitu Ida Ayu putu dan kawankawan(2019), Arslan dan Moudaki(2019), Dhir dan kawan-kawan(2019), Karatape(2013), Gupta dan kawan-kawan(2017), Nazir dan kawan-kawan(2017) serta Obuobisa(2019). Jurnal terbagi menjadi dua yaitu dibawah 2017 sebanyak 1 jurnal dan diatas 2017 sebanyak 6 jurnal. Untuk Publisher hanya ada 4 yaitu Springer, World Scientific, Elsevier(Science Direct) dan Emerald. Sampel dibawah 400 sebanyak 3 jurnal dan sampel diatas 400 sebanyak 4 jurnal. Sedangkan jenis penelitian hanya 1 yaitu kuantitatif. Bisnis Kegiatan berupa Public Sector sebanyak 1, Hotel sebanyak 2, Hospital Management sebanyak 1, Higher Education sebanyak 1 dan Holding sebanyak 1 jenis kegiatan usaha. 


\section{SIMPULAN DAN SARAN}

Bila dilihat dari analisis Word Frequency Analisis bahwa sebanyak 10 jurnal valid atau fokus pada variabel Employee Engagement dan Employee Performance yang merupakan bagian pokok dari studi literatur untuk kedua variabel tersebut.

Pada Bagian Analisis Klaster bahwa 10 jurnal ternyata membentuk 2 bagian yaitu Employee Engagement Eksogen yaitu Variabel bersifat mempengaruhi dan Employee Engagement Intervening yaitu bersifat mempengaruhi variabel eksogen terhadap variabel endogen, dan semua variabel ini bersifat positif terhadap variabel Employee Performance.

Untuk Project Map adalah klasifikasikan lebih rinci untuk masing-masing tema dari Variabel Engagement Eksogen dan Intervening. Sifat Positif di temakan menjadi Berpengaruh Positif pada Variabel Employee Performance, dimana dirincikan menjadi bagian Tahun Riset, Publisher, Bisnis, Jenis Riset dan Jenis sampel.

Sedangkan pada Diagram Perbandingan, bahwa Publisher yang paling banyak mempengaruhi dari kajian literature ini adalah menggunakan Elsevier (Science Direct) dan Emerald. Data sampel yang digunakan rata-rata diatas 400 sampel. Untuk Jenis Penelitan Kuantitatif lebih dominasi dibandinkan pada kualitatif. Sedangkan Bisnis yang lebih dominan mengarah pada Hotel dan Hospitality serta Skala Industri Kecil dan Menengah

Saran untuk penelitian selanjutnya adalah memperbesar jumlah sampel dan memfokuskan pada kegiatan bisnis tertentu saja sehingga keputusan akan lebih tepat dan mempunyai implikasi yang baik terhadap kegiatan perusahaan nanti.

\section{DAFTAR RUJUKAN}

Arslan, M., \& Roudaki, J. (2019). Examining the role of employee engagement in the relationship between organisational cynicism and employee performance. International Journal of Sociology and Social Policy, 39(1-2), 118-137. https://doi.org/10.1108/IJSSP06-2018-0087

Ayu Putu Widani Sugianingrat, I., Rini Widyawati, S., Alexandra de Jesus da Costa, C., Ximenes, M., Dos Reis Piedade, S., \& Gede Sarmawa, W. (2019). The employee engagement and OCB as mediating on employee performance. International Journal of Productivity and Performance Management, 68(2), 319-339. https://doi.org/10.1108/IJPPM-03-2018-0124

Bandur, A. (2016). Penelitian kualitatif Metodologi, Desain dan Teknik Analisis Data dengan Nvivo 11 plus. jakarta: Mitra Wacana Media.

Bedarkar, M., \& Pandita, D. (2014). A Study on the Drivers of Employee Engagement Impacting Employee Performance. Procedia - Social and Behavioral Sciences, 133, 106115. https://doi.org/10.1016/j.sbspro.2014.04.174

Bungin B. (2011). Metodologi Penelitian Kualitatif. jakarta: rajawali pers.

Bunting, M. (2011). Willing Slaves: How the Overwork Culture is Ruling Our Lives. HarperCollins.

Cardy, R. L. (2004). Performance management: Concepts, Skills, and Exercises. New York (NY): M.E. Sharpe, Armonk,

Cesário, F., \& Chambel, M. J. (2017). Linking Organizational Commitment and Work Engagement to Employee Performance. Knowledge and Process Management, 24(2), 152-158. https://doi.org/10.1002/kpm.1542

Chalofsky, N. (2003). An emerging construct for meaningful work. Human Resource Development International, Vol. 6(No. 69-83. https://doi.org/https://doi.org/10.1080/1367886022000016785 
CIPD. (2006). How engaged are British employees?. Annual Survey Report.

Cook, S. (2012). The essential guide to employee engagement. Kogan Page.

Csikszentmihalyi, M. (1982). Beyond Boredom and Anxiety. Jossey Bass.

Deddy mulyana. (2004). Metodologi Penelitian Kualitatif (Paradigma Baru Ilmu Komunikasi Dan Imu Sosial lainnya). Bandung: PT Remaja Rosmadakarya,.

Delery, J.E. and Doty, D. H. (1996). "Modes of theorizing in strategic human resources management: test of universalistic, contingency, and configurational performance predictions." Academy of Management Journal, Vol. 39(No. 4), 802-835.

Elsi anismar et al. (2019). Platform Pemberdaya UMKM. SWA, 22-47.

Espitia et al. (2016). Systematic Literature Review of the Implementation of Knowledge Codification Process. In European Conference Knowledge Management (p. 1111). Passau: Academic Conferences International Limited.

Fahmi, I. (2014). Perilaku Organisasi. bandung: Alfabeta.

Flemming, J.H. and Asplund, J. (2007). Where employee engagement happens.

Gatenby, M., R. C., \& Soane, E., Truss, C. (2008). Employee Engagement in Context. London: Chartered Institute of Personnel and Development.

Goffman, E. (1961). Encounters. Harmondsworth: Penguine University Books.

Hausknecht, J.P., Rodda, J. and Howard, M. . (2009). Targeted employee retention: performance-based and job-related differences in reported reasons for staying. Human Resource Management, Vol. 48(no 2), 269-288. https://doi.org/https://doi.org/10.1002/hrm.20279

Hewitt Associates LLC. (2004). Research Brief: employee engagement higher at double digit growth companies, at. Retrieved March 25, 2013, from www.hewitt.com.

J., A. (2014). Determinants of employee engagement and their impact on employee performance. International Journal of Productivity and Performance Management, 63(3), 308-323. https://doi.org/10.1108/IJPPM-01-2013-0008

Joplin, T., Greenbaum, R. L., Wallace, J. C., \& Edwards, B. D. (2019). Employee Entitlement, Engagement, and Performance: The Moderating Effect of Ethical Leadership. Journal of Business Ethics, (0123456789). https://doi.org/10.1007/s10551-019-04246-0

Katz, D. And Kahn, R. L. (1966). The Social Psychology of Organisations. new york, NY: Wiley.

Kular, S., Gatenby M., Rees, C., Soane, E. and Truss, K. (2008). Employee Engagement: A Literature Review. Kingston University.

Macey, W.H., Schneider, B., Barbera, K.M. and Young, S. A. (2009). Employee Engagement: Tools for Analysis, Practice, and Competitive Advantage. Wiley-Blackwell, Malden, WA.

Macey, W.H. and Schneider, B. (2008). "The meaning of employee engagement". Industrial and Organizational Psychology., Vol. 1.(No. 1.), . pp. 3-30.

May, D.R. Gilson, R.L. andHarter, L. M. (2004). The psychological conditionsof meaningfulness, safety and availability and the engagement of the human spirit at work. Journal of Occupational and Organisational Psychology., 77, 11-37.

Nazir. (2014). Metode Penelitian. jakarta: Ghalia Indonesia.

Nazir, O., \& Islam, J. U. (2017). Enhancing organizational commitment and employee performance through employee engagement: An empirical check. South Asian Journal of Business Studies, 6(1), 98-114. https://doi.org/10.1108/SAJBS-04-2016-0036

Newman, D.A. and Harrison, D. A. (2008). Been there, bottled that: are state and behavioural work engagement new and useful construct;wines'?. Industrial and Organisational Psychology, 1, 31-35.

Rivai, V. (2009). Manajemen Sumber Daya Manusia untuk Perusahan. Jakarta: PT. RajaGrafindo Persada.

Robinson, D. Perryman S. and Hayday, S. (2004). The Drivers of Employee Engagement. 
Institute for Employment Studies.

Saks, A. M. (2006). Antecedents and consequences of employee engagement. Journal of Managerial Psychology, 21((7)), 600-619.

Shaufeli.W.B., Salanova, M., Gonzalez, R. V. and Bakker, A. B. (2002). The measurement of engagementand burnout: a two sample confirmatory factor anlytic approach. Journal of Happiness Studies., 3, 71-92.

shaufeli.W.B. and Bakker, A. B. (2004). Job demands, job resources, and their relationship with burnout and engagement: a multi sample study. Journal of Organisational Behaviour., Vol.(No. 25), 293-315.

Sugiyono. (2014). Metode Penelitian Kuantitatif, Kualitatif, dan Kombinasi (Mixed Methods). Bandung: alfabeta.

Sutrisno, E. (2016). Manajemen Sumber Daya Manusia. Jakarta: Prenadamedia Group.

Truss, C., Soane, E., Edwards, C., Wisdom, K., Croll, A. and Burnett, J. (2006). Working Life:Employee Attitudes and Engagement. London: Chartered Institute of Personnel and Development.

Wibowo. (2007). Sistem Mananjemen Kinerja,. jakarta: PT. Raja Grafindo Persada.

Wildermuth, C. \&Pauken, P. D. (2008). A Perfect math:decoding employee engagement-PartI: Engaging cultures and leaders. Industrial and Commercial Training, Vol 40(No.3), pp.122-128.

winanti. (2011). Majalah UNIKOM. Jurnal Majalah Ilmiah Unikom. Jurnal Majalah Ilmiah Unikom. 